\title{
US sends mixed message in GM debate ...
}

[WASHINGTON] In what had been billed as a major policy speech, US Agriculture Secretary Dan Glickman moved to ease public worries over genetically modified (GM) crops last week by acknowledging the need for unbiased research that would assure their safety.

But he stopped short of calling for the compulsorylabelling of GM foods, and spoke of a US willingness to "vigorously fight for our legitimate rights" in trade negotiations with Europe over biotechnology products.

In his speech, Glickman announced several steps designed to bolster consumer confidence in GM foods. The US Department of Agriculture (USDA), which is responsible for evaluating the risks of biotechnology products to plants and animals, will initiate an independent review of the science behind product approval. This would presumably be conducted by the National Research Council, part of the National Academy of Science complex, which is already examining US Environmental Protection Agency (EPA) regulation of GM pest-resistant plants.

Glickman stressed the importance of separating USDA's research activities from its efforts to promote US agriculture "to ensure that no commercial interests have even the appearance of influence on our decisions regarding food safety". He also called for the establishment of regional centres "to evaluate biotech products over a long period of time and to provide information on an ongoing basis to growers, consumers, researchers and regulators".

But details of the work these centres will do remains sketchy, and it is uncertain whether they will conduct long-term ecological studies of GM crops. USDA spokesman

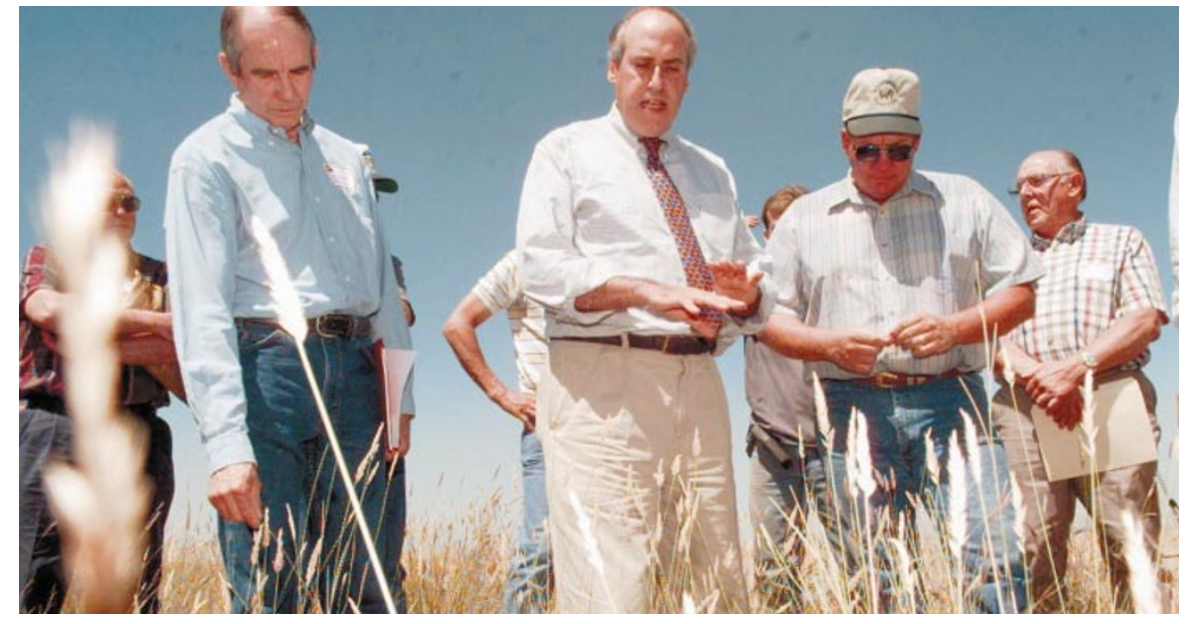

Field work: Glickman (centre, in tie) is seeking to satisfy both advocates and critics of GM crops.

Andy Solomon said there will be 8 to 12 such centres, which would be funded next year from the department's existing budget, with a request for additional funding likely in 2001.

Just as vague was Glickman's call for “all developers of biotech products to report any unexpected or potentially adverse effects to the Department of Agriculture immediately upon discovery". Val Giddings, vice-president for food and agriculture at the Biotechnology Industry Organization (BIO), points out that this requirement already exists for GM foods undergoing field tests before commercial release. Any reporting after commercial release would probably be strictly voluntary, says a USDA source.

Glickman received mostly favourable reactions from both sides of the GM food debate. BIO president Carl Feldbaum called it a "good speech" and said "I don't think it was in any way a blow" to the biotech industry.

\section{... as questions emerge over cost-effectiveness}

[WASHINGTON] The jury is still out on whether expensive, genetically modified (GM) commercial crops will be cost-effective for farmers in the long run, according to a study conducted for the Biotechnology Industry Organization $(\mathrm{BIO})$ and released in Washington last week.

Genetically modifying corn to produce the Bacillus thuringiensis $(B t)$ toxin, which kills the destructive European corn borer, has increased crop yields. US farmers planting such Bt corn gained $\$ 72$ million in 1997 compared with conventional varieties.
But the following year, when three times more acreage was planted with $B t$ corn, growers lost \$26 million as pest infestation levels were low and the price of corn dropped to well below average levels.

Because these factors vary from year to year, the economics of GM crops will only become clear in the long term. Based on historic trends in pest infestation, farmers planting Bt corn can expect three non-paying years every decade. The study, based on the first two to three years of commercial field usage, was conducted for BIO by the National Center for Food and Agricultural Policy, a non-profit-making institute based in Washington.

Reductions in pesticide use were slight, too: although 18 per cent of US corn planted last year was of the $B t$ variety, the use of insecticide dropped on only 2.5 per cent of corn acreage. But $B t$ cotton farmers fared better, gaining $\$ 92$ million in net income in 1998 by planting GM crops. Potato farmers, meanwhile, have yet to adapt to large-scale use of Bt strains as they still need to apply insecticide to control other pests.
Rebecca Goldburg of the Environmental Defense Fund, which has led the campaign to raise awareness of the risks of GM crops, said that Glickman "lent considerable legitimacy" to concerns about those risks.

Glickman acknowledged reports of possible harm to monarch butterflies (see Nature 399, 287; 1999) but added that there has been no evidence of any harmful effects in the field.

"I believe that distrust [of GM foods] is scientifically unfounded," he said. European reaction "comes in part from the lack of faith in the European Union to assure the safety of their food. They have no independent regulatory agencies like the [Food and Drug Administration], USDA or EPA."

Regarding the dispute over whether GM foods should be labelled in supermarkets a practice the US biotech industry opposes — Glickman was again diplomatic. "At the end of the day, many observers, including me, believe some type of informational labelling is likely to happen," he said. "But I do believe that it is imperative that such labelling does not undermine trade and this promising new technology."

On the matter of trade negotiations with Europe, Glickman was uncompromising and emphatic. "We cannot let others hide behind unfounded, unwarranted scientific claims to block commerce in agriculture," he said. This, and his statements espousing the promise of GM crops, led Giddings to pronounce the speech a "robust endorsement of biotechnology".

Yet Glickman also called for the biotech industry to act responsibly and take public concern into account. "Product development to date has enabled those who oppose this technology to claim that all the talk about feeding the world is simply cover for corporate profit-making," he said, adding that "industry needs to act with greater sensitivity and foresight".

Tony Reichhardt 